$\overline{\text { 原 著 }}$

\title{
妊婦および褯婦の終夜睡眠 一睡眼の主観的評価と睡眠ポリグラフ所見一
}

\author{
堀 内 成 子*・近 藤 潤 子*・小 山 真理子* \\ 木 戸ひとみ*・大久保 功子*・山 本 卓 二** \\ 岩 澤 和 子***
}

\section{Nocturnal Sleep During Pregnancy and Postpartum Periods}

\section{-The Relationship Between Subjective Evaluation and Polygraphic Findings-}

\author{
Shigeko Horiuchi*, Junko Kondo*, Mariko Koyama*, Hitomi Kido*, \\ Noriko Ohkubo*, Takuji Yamamoto**, Kazuko Iwasawa*** \\ * St. Luke's College of Nursing, ** Psychiatric Rsearch Institute of Tokyo \\ *** Public Health Unit of Fujisawa
}

\begin{abstract}
This study was undertaken to find out the relationship between subjective evaluation on sleep and nocturnal polygraphic findings in women during pregnancy and postpartum periods, and also to detect the changes of sleep patterns during those periods.

Seven women in 11 to 37 weeks of pregnancy and four in 1 to 7 weeks of post-partum period were studied. Four non-pregnant healthy women selected as a control group. Nocturnal sleep recordings included EEG, EOG, EMG, and ECG. The data were recorded during three consecutive nights, and sleep records were scored according to the criteria outlined by Rechtshaffen \& Kales. The data on subjective evaluation were collected by using a questionnaire.

It was found that two types of subjective evaluation of sleep among the subjects; one was a mono-phasic pattern, and the other was a multi-phasic pattern. In the women with a mono-phasic type, the polygraphic findings showed normal sleep pattern.

The sleep efficiciency rate of the pregnant group, especially in the third trimester, was lower and the sleep was poor than that of the non-pregnant group, The sleep efficiency rate in the early postpartum period was further lower than that in the third trimester of pregnancy, though \%S4 increased.
\end{abstract}

\footnotetext{
*聖路加看護大学 $\quad * *$ 東京都精神医学総合研究所 $\quad * * *$ 藤沢市役所
}

受理：平成 2 年 5 月 31 日 Accepted: May 31, 1990 
本研究は，妊婦および裖婦の睡眠の主観的評価と睡眠ポリグラフ所見との間の関連性を 明らかにすること，および妊婦各期と産裖早期の睡眠推移を明らかにすることを目的に終 夜睡眠を分析した。

妊婦11週〜37週までの正常妊婦 7 例と, 産裖 1 週〜 7 週までの正常裖婦 4 例を対象とし, 終夜睡眠をポリグラフ装置で連続 3 夜測定した。睡眠段階はRechtshaffen \& Kales の判定 基準を用いた。対照群として健康な非妊期の女性 4 例を選び, 測定した.

その結果, 主観的な睡眠深度経過では, 前半単相性パターンと前半多相性パターンとに 分かれ，ポリグラフ所見との間に関係が認められた。睡眠パラメータでは, 妊婦群が非妊 婦群に比べて睡眠率が低く，特に末期群では眠りが浅くなっていた。産裖早期には，妊娠 末期よりさらに睡眠率が低かったが，妊婦末期に比べて\%S4は増加の傾向が認められた。

\section{はじめに}

眠りの量や質は人々の心身の健康状態に影響 を及ぼす。妊娠・産褲期は, 女性の一生の中で も最も急激に心身の健康状態が变化する時期で ある.この時期の眠りはどのように変化するの であろらか. 我々は, 先に妊婦を対象とした睡 眠の主観的評価の調査を行い1), 妊娠の進行に 伴って睡眠に変化を生じ, 妊娠末期の方が, 睡 眠が不良で, 不満足感のあることを明らかにし た. 同様に産裖早期の調査では ${ }^{2}$, 妊娠末期よ りさらに睡眠についての不満足感が高まっていた。 睡眠研究は, 主観的側面之, 客観的・生理学 的側面の双方の研究が必要である. しかし従来, 女性は月経周期といら変動要因が大きいために, 睡眠研究の対象から除外されることが多く, 正 常妊婦の終夜睡眠の測定は，1960年代にKaracan ら3)や, Petre-Quadensら4)の報告があるにす ぎない，今回は妊婦㐨よび裖婦の終夜睡眠につ いて, 睡眠の主観的評価と, 睡眠ポリグラフ所 見との関係を分析・考察した.

\section{目的}

1. 妊婦及び裖婦の睡眠の主観的評価と睡眠ポ リグラフ所見との間の関連性を明らかにす る.

2. 妊娠初期 - 中期 - 末期 - 産裖早期の各時期 毎の終夜睡眠の推移を明らかにする.

\section{対象および方法}

月経周期が規則的である健康な非妊婦 4 例, 妊娠11週〜37週までの経過が正常である妊婦 7 例, 産裖 1 週〜 7 週までの経過が正常である裖 婦 4 例を対象として, 終夜睡眠をポリグラフ装 置で測定した。調査期間は昭和 62 年 5 月から昭 和63年10月であった. 非妊婦は未婚で年龄は全 例21歳であった. 非妊婦は月経周期のらち, 低 温期および高温期に測定した。妊婦の年齢範囲 は24 31歳, 平均年齢27歳であり, 妊娠初期 (11 週) 1 例, 中期 (23 26週) 3 例, 末期 (29〜37週) 3 例であった。産歴は全例初産婦であった。裖 婦(産裖1 7 週) の年齢範囲は29〜32歳で, 平均 年齢31歳であった. 産歴は 1 例が初産婦, 3 例 が経産婦であった。

非妊婦および妊婦は検査室で, 䙏婦は家庭で 測定した。検査室の広さは, $20 \mathrm{~m}^{2}$ で半防音状 態で, ベッド, 机, 布団等は被験者の通常の習 慣を加味して工夫した。被験者は, 本人の平素 の就床時刻に就床でさるように, 約 3 時間前に 検査室に来室し自由にすごしたのち, 約 1.5 時 間前より各種電極の装着を行なった。裖婦は, 新生児と同じ平素の寝室で測定した。ポリグラ フは, 脳波・眼球運動・筋電図・心電図を測定 するために, 各々 $2 つ$ 電極を対象者に装着し, テレメータ受信ユニット $(\mathrm{ZR}-601 \mathrm{G}$ 型：日本光 電製)を用い，データレコーダ $(\mathrm{A}-64$ 型) に収録 し, 熱書記録器 $(\mathrm{PJG}-4124$ 型 : 日本光電製) で 
再生した. 連続 3 夜測定し, 第 1 夜を順応夜と し，第 2 夜・第 3 夜をデータとして用いた。睡 眠段階はRechtshaffen \& Kales ${ }^{5)}$ の測定基準を 用いて視察的に 1 分ごとに判定した.

データの分析は，各事例別に睡眠経過図を概 観し，さらに睡眠パラメータを算出した。睡眠 のパラメータとしては, 全睡眠時間(TST)・睡 眠率 $(\mathrm{SEI}) \cdot$ 入眠潜時 $(\mathrm{SL}) \cdot$ 途中覚醒 $・ R E M$ 持続時間 - REM 周期 - 睡眠段階移行数 - 覚醒 時間 (SW) ・TST K対する各睡眠段階の比率 （\%REM•\%S1〜\%S4）を算出した.今回は第 2 夜 を分析したので，結果を報告する.

測定夜の睡眠の主観的評価を調べる為に, 先 に昭和 62 年の我々の調査で関連因子間の関係が 明らかになった調査項目を用いた。さらに, 測 定夜の主観的な睡眠深度経過図をRechtshaffen \& Kales の国際分類と対比して 6 段階に分け, 経時的に記録した。

\section{結果}

1. 睡眠の主観的評価とポリグラフ所見

(1) 非妊婦群

非妊婦群は月経周期のらち, 低温期と高温期
に測定したが，睡眠のパラメータの分析結果に 著しい相違がみられなかったので，今回分析の 対象としたのは内分泌環境が妊娠と類似してい る高温期とした。

非妊婦群の睡眠の主観的評価は, 全例が寝つ き・深さ・時間の長さ・起床時の気分が良好で 全体として満足感を示していた。（表 1 一事例A. B. C. D. 参照)

主観的な睡眠深度経過図の変化は大部分が, 入眠から徐々に深くなり, 明け方にやや浅くなっ た後に覚醒に至る前半単相性パターンであった. (図 1 参照)

ポリグラフ所見は, 睡眠段階が入眠後, Stage1 (以下 $\mathrm{S} 1$ と略す)・S2・S 3 ・S 4 と睡眠は徐々に深く なり, 事例 Cを除いて, 約 1 時間半後には眠り が浅くなり， REM 睡眠が出現していた. その 後, このNONREM-REM 睡眠サイクルをくり かえし, 起床に至るという通常の健康成人の睡 眠経過を示していた。

主観的な途中覚醒は, 事例Bが「夢」で, 事 例 C は「足のこむらが党り」で 1 回ずつ知覚し ていたが，ポリグラフ上では明らかなWakeは 認められなかった。

表 1 測定夜の主観的睡眠評価

\begin{tabular}{|c|c|c|c|c|c|c|c|c|c|c|c|c|}
\hline \multirow{2}{*}{\multicolumn{2}{|c|}{ 症例 }} & \multirow{2}{*}{$\begin{array}{l}\text { 入眠の* } \\
\text { 難易度 }\end{array}$} & \multirow{2}{*}{ 時間の長さ* } & \multirow{2}{*}{ 眠りの深さ* } & \multirow{2}{*}{$\begin{array}{l}\text { 途中覚醒に** } \\
\text { 対する気持ち }\end{array}$} & \multirow{2}{*}{$\begin{array}{l}\text { 起床の } \\
\text { 難易度 }\end{array}$} & \multicolumn{5}{|c|}{ 起床時の気 分**** } & \multirow{2}{*}{ 満 足 感* } \\
\hline & & & & & & & 爽快さ & \multicolumn{2}{|c|}{ 疲労回復感 } & \multicolumn{2}{|c|}{ 熟眠感 } & \\
\hline \multirow{4}{*}{$\begin{array}{l}\text { 非 } \\
\text { 妊 } \\
\text { 婦 } \\
\text { 群 }\end{array}$} & A & よい & 十 分 & 深 い & 覚醒なし & 易 & 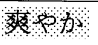 & 60 & 8 & 6 & & 満 足 \\
\hline & B & - & 十 分 & 深 い & 嫌犬゙,不快,恐心 & 少し難 & 爽やか & 6. & r & 60 & 0 & 満 足 \\
\hline & $\mathrm{C}$ & +1, & $1 / \sqrt{ }$ & s' & 驚 き & 少し難 & 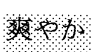 & 6 & 9 & 6 & 9 & 渾 \\
\hline & $\mathrm{D}$ & 41 & । & 1 穼 1 & 覚醒なし & 易 & 筩 & 6 & 8 & 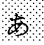 & 8 & 清 \\
\hline \multirow{3}{*}{ 妊 } & $\mathrm{E}$ & + & 十 分 & 深 い & 何とも思わない & 易 & 爽やか & 10 & 9 & あ & & どちらとむい光ない \\
\hline & $\mathrm{F}$ & 10 & 4 ; & 8 & 何とも思わない & 易 & 爽やか & b) & 6 & 8 & . & $\mathrm{r} / \mathrm{r}$ \\
\hline & G & よい & 十 分 & 深 い & $\begin{array}{l}\text { 嫌だ，しかた } \\
\text { ない }\end{array}$ & 易 & 80 & D. & 1 & 万) & 6 & 滆 \\
\hline \multirow{2}{*}{ 婦 } & $\mathrm{H}$ & 悪い & 不 足 & どちらともい光ない & しかたがない & 易 & な し & な & ᄂ & あ & $\eta$ & どちらとむい党ない \\
\hline & I & よい & 415 & 8 穼 & 何とも思わない & 易 & $\times>$ & あ & $\eta$ & あ & $\eta$ & 淦 \\
\hline \multirow{2}{*}{ 群 } & $J$ & よい & 十 分 & 深 い & 何とも思わない & 少し難 & 爽やか & あ & $\eta$ & あ & $\eta$ & $\sqrt{7}, \sqrt{1}$ \\
\hline & $\mathrm{K}$ & 1) & $1, j$ & \% & 何とも思わない & 易 & 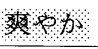 & \$) & 6 & \$ & 6 & 济 \\
\hline \multirow{4}{*}{$\begin{array}{l}\text { 裖 } \\
\text { 婦 } \\
\text { 群 }\end{array}$} & $\mathrm{L}$ & +1 & 十 分 & 梁 & しかたがない & 易 & 爽やか & あ & $\eta$ & あ & $\eta$ & 満 足 \\
\hline & M & 1) & どちらともい壳ない & \% & しかたがない & 少し難 & なし & あ & $\eta$ & な & L & 不 満 \\
\hline & $\mathrm{N}$ & 4 & 1 , & s' & しかたがない & 少し難 & 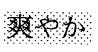 & あ & $\eta$ & 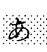 & 4 & 渾 \\
\hline & $\mathrm{O}$ & 墨l & 十 分 & 深 い & しかたがない & 易 & 爽やか & な & ᄂ & あ & $\eta$ & 満 足 \\
\hline
\end{tabular}




\section{(2) 妊婦群}

妊婦群の睡眠の主観的評価は, 睡眠時間の短 かった事例 $\mathrm{H}$ を除き， 6 例が寝つき・深さ・時 間の長さが良好で，起床時の気分にやや眠気が 残るが，全体として満足感を表していた。（表 1 -事例E. F. G. H. I. J. K. 参照)

主観的な睡眠深度経過図では非妊婦群のそれ と類似した前半単相性パターンを示すもの( 3 例：事例E.F.G, 図 2 参照) と, 入眠後に睡 眠は深くなるが，比較的早期に浅眠感を持ち， その後も深度に $2 \sim 3$ 回の変動を示す, 前半多
相性パターン ( 4 例 : 事例H.I.J.K, 図 3 参 照)が認められた。

ポリグラフ所見は，主観的な睡眠深度の評価 で前半単相性パターン示していた事例 E.F.G の場合は非妊婦群と同様であった。 また，途中 覚醒は主観的には，事例E. F K $2 \sim 3$ 回知覚さ れていたが，ポリグラフ上には非妊婦群と同様 に，明らかなWakeが認められなかった。

一方, 主観的睡眠深度の評価が非妊婦群之は 異なり，前半多相性パターンを示していた事例 のポリグラフ所見では， 入眠後 $\mathrm{S} 1 \cdot \mathrm{S} 2 \cdot \mathrm{S} 3 \bullet \mathrm{S} 4$ と
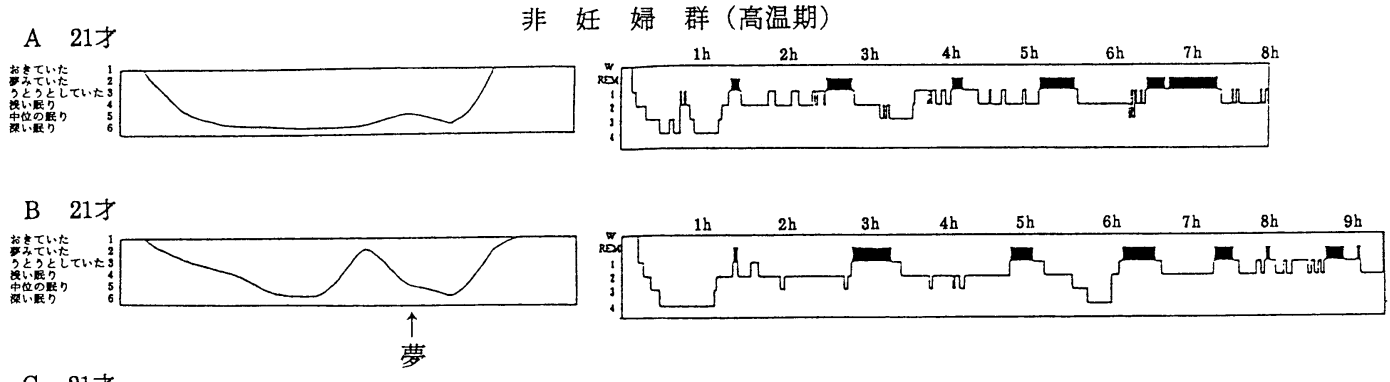

C 21才
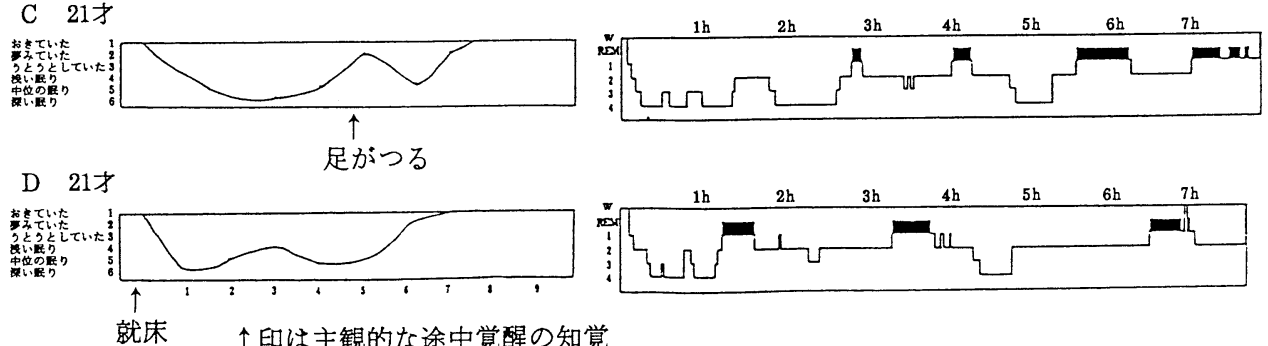

就床印は主観的な途中覚醒の知覚

図 1 主観的な睡眠深度経過とポリグラフ所見

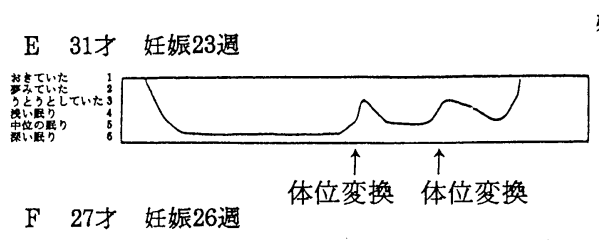

妊 婦 群
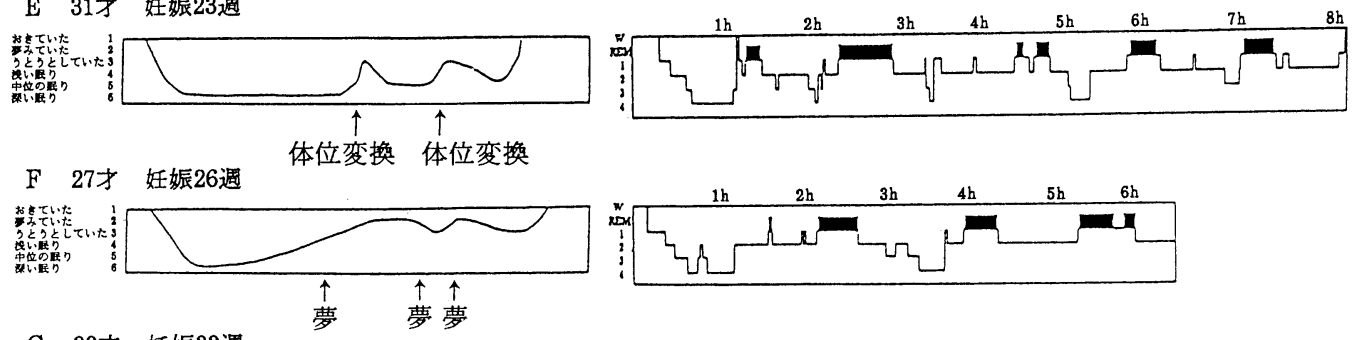

G 30才 妊娠33週
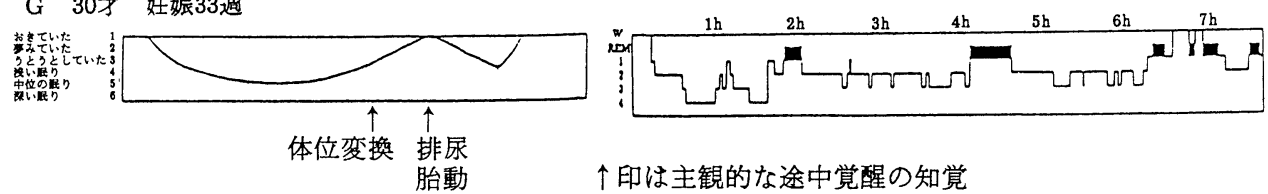

个印は主観的な途中覚醒の知覚

図 2 主観的な睡眠深度経過とポリグラフ所見 


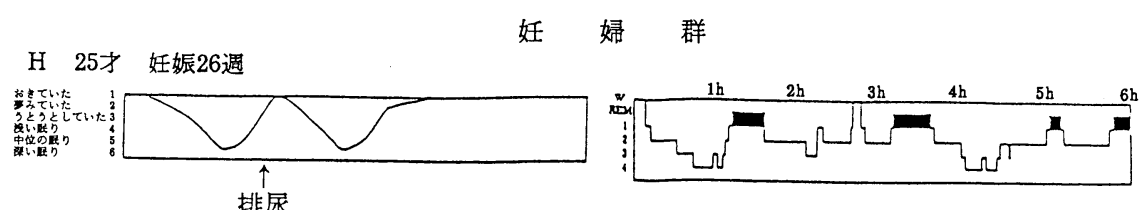

I 26才 妊娠11週
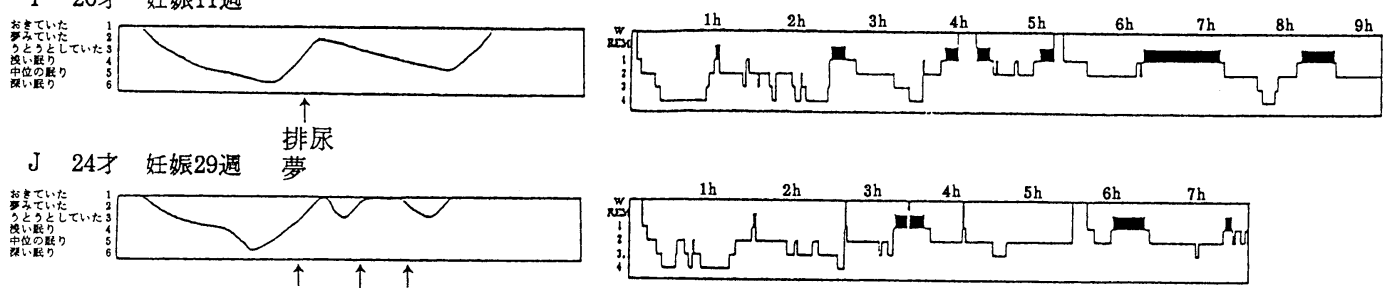

K 26才 妊娠37週

体位変換 排尿 足がつる
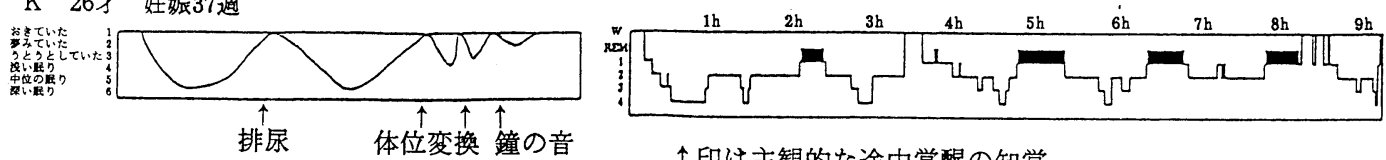

个印は主観的な途中覚醒の知覚

図 3 主観的な睡眠深度経過とポリグラフ所見

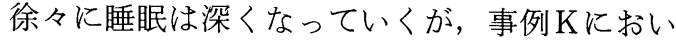
ては，第 1 睡眠周期のREM の出現の遅れが認 められた. また，事例 $\mathrm{H}$ I とには，睡眠の後 半期にもS4が現れていた。また途中覚醒は主 観的にも, ポリグラフ上にも，全例に $2 \sim 3$ 回 認められ, 覚醒時期も類似していた. 覚醒の理 由は, 体位変換や排尿のためであった。（図 3 参照)

\section{(3) 裖婦群}

裖婦群では, 4 例中 1 例(事例M)が時間の長 さ・起床時の気分が不良で, 全体に不満足感を 示していたが，他の 3 例は睡眠全体に満足感を 示していた.

主観的な睡眠深度経過図では, 前半単相性パ ターンを示すもの（1例 事例 L ) と，入眠後に 睡眠が深くなるが，その後比較的長時間の途中 覚醒が入り, 再び眠りにつき起床に至る, 前半 多相性パターン ( 3 例：事例M.N. O) とがあっ た.（図 4 参照）

ポリグラフ所見を見ると， 入眠後 $\mathrm{S} 1 \cdot \mathrm{S} 2 \cdot \mathrm{S} 3 \cdot \mathrm{S} 4$ と睡眠は徐々に深くなり，そののち浅くなって， 約 1 時間半後にREM 睡眠期が認められる.そ の後途中に比較的長時間(10分〜 60分)の授乳や， おむつ替えなどのための途中覚醒が認められた。 睡眠後半期の第 3 および第 4 睡眠周期において
も，S3・S4の徐波睡眠が全例に認められた.

途中覚醒については，主観的にも，ポリグラ フ所見上にも認められていたが，産裖週数によ り特徵があった。産褛 1 週目の事例 0 は, ポリ グラフ上の 1 回の覚醒時間が長く, それに対し て産褯 3 週目の事例M.N よりポリグラフ上での覚醒が断続的に生じてい た.さらに産裖 7 週目の事例 $\mathrm{L}$ は覚醒回数の点 では主観的知覚とポリグラフ所見は一致するが， 主観的深度は就床から起床まで「中位」から 「深い眠り」であり, 睡眠深度の变動は知覚さ れていなかった。

\section{2. 睡眠のパラメータ(表 2 参照)}

1) <全睡眠時間 (TST) >

全睡眠時間は, 裖婦群が非妊婦群に比べて有 意に $(\mathrm{p}<0.01)$ 低い結果であった.

2 ) <睡眠率 (SEI：覚醒時間を除外した全睡 眠時間の全記録時間に対する割合>

SEI は，非妊婦群に比べ妊婦群は初期・中期 および末期群それぞれが有意に $(\mathrm{p}<0.01, \mathrm{p}<0.001)$ 低い結果であった。 また妊娠末期群は, 初期・ 中期群に比べて $(p<0.05)$ 低い傾向があった. また, 褯婦群は, 非妊婦群に比べて有意 $(\mathrm{p}<0.01)$ に低く，妊娠各期に比べ低い傾向 $(p<0.05)$ が 

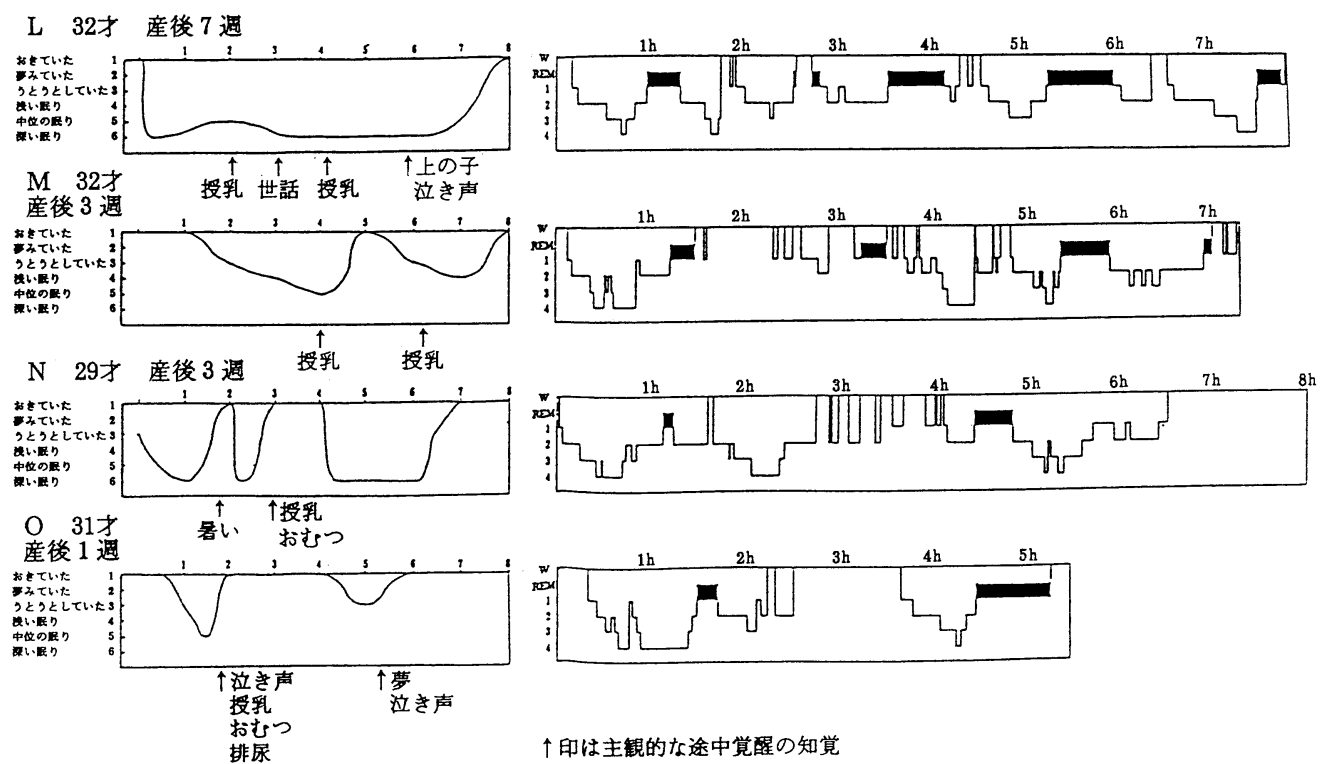

図 4 主観的な睡眠深度経過とポリグラフ所見

表 2 非妊婦・妊婦・裖婦別睡眠パラメー夕平均值の一覧

\begin{tabular}{|c|c|c|c|c|c|}
\hline & 非妊婦群 & 婦 & 群 & 裖 婦 群 & \\
\hline 睡眠パラータ & $\begin{array}{l}\text { 高温期 } \\
\mathrm{n}=4\end{array}$ & $\begin{array}{c}\text { 初期・ 中期群 } \\
\mathrm{n}=4\end{array}$ & $\begin{array}{l}\text { 末期群 } \\
\mathrm{n}=3\end{array}$ & $\begin{array}{c}\text { 産裖早期群 } \\
\mathrm{n}=4\end{array}$ & $\mathrm{t}$ 検 定 \\
\hline $\mathrm{TST}(\min )$ & $485.3^{\text {a) }}$ & 442.0 & 459.7 & $329.0^{\mathrm{b})}$ & a) - b) $* *$ \\
\hline SEI $(\%)$ & $98.0^{\mathrm{c})}$ & $95.9^{\mathrm{d})}$ & $93.5^{\mathrm{e})}$ & $75.6^{\mathrm{f})}$ & c) - d) $* *$ c) - e)*** d) - e)* \\
\hline $\mathrm{SL}(\min )$ & 11.8 & 18.0 & 12.3 & 14.0 & c) $-\mathrm{f}) * * \quad$ d) $-\mathrm{f}) * \quad$ e) $-\mathrm{f}) *$ \\
\hline 途中覚醒 $(\mathrm{min})$ & $0.5^{\mathrm{g})}$ & $7.0^{\mathrm{h})}$ & $19.7^{\mathrm{i})}$ & $66.0^{\mathrm{j})}$ & g) - j) $* * \quad$ h) - j) $* * \quad$ i $)-j$ )* \\
\hline 途中覚醒(回) & $0.3^{\mathrm{k})}$ & $1.0^{1)}$ & $3.3^{\mathrm{m})}$ & $7.5^{\mathrm{n})}$ & $\mathrm{k})-\mathrm{m}) * * *(\mathrm{l})-\mathrm{m}) * \mathrm{k})-\mathrm{n}) *$ \\
\hline $\mathrm{REM}$ 持続 (min) & 19.6 & 19.4 & 16.3 & 22.5 & \\
\hline $\mathrm{REM}$ 周期 (min) & 79.9 & 65.1 & 80.5 & 86.5 & \\
\hline 睡眠段階移行数 (回) & 49.5 & 44.5 & 54.0 & 49.3 & \\
\hline$\%$ REM & 21.0 & $23.4^{\mathrm{o})}$ & $17.8^{\mathrm{p})}$ & 22.2 & o) $-\mathrm{p}) *$ \\
\hline $\mathrm{SW}(\min )$ & 9.8 & 19.5 & 32.7 & 102.5 & \\
\hline$\% \mathrm{~S} 1$ & 9.0 & 7.2 & 6.9 & 11.7 & \\
\hline$\% \mathrm{~S} 2$ & 49.0 & 50.2 & 52.5 & 41.4 & \\
\hline$\% \mathrm{~S} 3$ & 6.7 & 7.2 & 13.7 & 12.4 & \\
\hline$\% \mathrm{~S} 4$ & 14.4 & 12.1 & 9.4 & 12.3 & \\
\hline 第 1 睡眠周期 (min) & 170.3 & 90.5 & 122.3 & 89.3 & \\
\hline
\end{tabular}

$*: \mathrm{p}<0.05 \quad * *: \mathrm{p}<0.01 \quad * * *: \mathrm{p}<0.001$

注：\%S1 とはTSTに対するS1の比率 $(\%)$ を示す. 
あった。

睡眠段階移行数は各群で差異はなかった. 途 中覚醒の時間では, 褯婦群が他のいずれの群よ りも有意に $(\mathrm{p}<0.01)$ 多かった.

$3)<$ 睡眠周期>

睡眠周期は妊娠時期別に差がなく, REM 持 続時間及びREM 周期も, 時期別の差異は認め られなかった，TSTに対するREMの比率は， 妊娠末期群の汪らが妊娠初期・中期に比べて （p<0.05）低い傾向であった.

$4 ）<$ 徐波睡眠期 (S3およびS4)>

徐波睡眠期として，\% S3とS4の総和をみる と, 妊娠末期群が $23.1 \%$ とやや高いが，より深 い睡眠の\%S4の占める比率は妊娠末期群に低かっ た. 妊娠時期と睡眠パラメータとの相関をみる 之, 妊娠週数と\%S4の間には $\mathrm{r}=-0.853(\mathrm{p}<0.01)$ で有意な負の相関が認められ，末期になるほど 深い睡眠の比率が小さくなる傾向があった．し かし, 裤婦群の\%S4は妊娠末期より増加傾向が 認められた。

また妊娠週数と第 1 睡眠周期との間に, $\mathrm{r}=$ $0.945(\mathrm{p}<0.001)$ で有意な相関が認められ，末 期になるほど第 1 周期が長くなる傾向があった. 第 1 周期のうちの\%S4は妊娠週数と $r=-0.779$ $(p<0.05) の$ 負の相関が認められた.

\section{考察}

1. 睡眠経過の主観的評価とポリグラフ所見

1) 主観的に見た睡眠深度の経過

非妊婦群は，主観的な睡眠深度経過図におい て, 前半単相性パターンであり, ポリグラフ所 見は通常の健康成人の睡眠を示していた。同様 に妊婦群の中で, 主観的な睡眠深度経過で前半 単相性パターンを示すものは ( 7 例中 3 例), ポ リグラフ所見でも非妊婦群と同様であった。

一方, 主観的な睡眠深度経過図で前半多相性 パターンを示す事例が, 妊婦群 ( 7 例中 4 例) と 褯婦群 ( 4 例中 3 例) に認められた。妊婦群では, 主観的睡眠深度の変化で比較的早期に浅眠感を もつ(事例J・K)場合であり，ポリグラフ所見で は途中覚醒が睡眠経過の前半に認められ, 事例 $\mathrm{K}$ では第 1 睡眠周期の延長が認められた。 小林
ら 6) 住, 健康な男子大学生 35 人の 140 夜の自然 睡眠での睡眠周期 (sleep cycle)について研究し, 第 1 睡眠周期の最初のS $3+4$ を経過後に, 本来 $\mathrm{S} 1$ +2 の時間帯に出現すべきREM 睡眠が何らか の原因でおさえられ，第 1 睡眠周期が延長した 場合のことを，第 1 睡眠周期における sleep と指摘している. 事例 $\mathrm{K}$ の第 1 睡眠周期 の延長はこれに該当すると考えられる。

また，妊婦群の中で睡眠深度経過図で前半多 相性パターンを示した事例 (I. H) と裖婦群の睡 眠深度が前半多相性パターンを示した事例 (M. N.O)は, 比較的長時間の途中覚醒が認められ る場合で, 通常のポリグラフ所見とは異なり,

第 3，4 睡眠周期において子徐波睡眠の出現が 認められた. Borbely7)によると，S3およびS4 の終夜睡眠経過中の出現シェーマにおいて, 途 中覚醒がなければ徐波睡眠期 (S3・S4) は第 1 睡 眠周期や睡眠の前半でその大半は出現するが， 途中覚醒があると徐波睡眠期が睡眠の前半で十 分あらわれずに後半期においても出現すると述 べている. この点においては, 本研究のポリグ ラフ所見で，S4が途中覚醒後の明け方の第 3 ・ 第 4 周期に出現していたことに一致する.

\section{2 ) 途中覚醒}

途中覚醒の回数の主観的知覚とポリグラフ所 見との間には，泳ぼ一致する場合と解離を示す 場合とが認められた。

解離を示す場合は, 主観的覚醒のみでポリグ ラフ上には認められない事例(非妊婦群 : B・C 及び妊婦群 : $\mathrm{E} ・ \mathrm{~F})$ と, 主観的覚醒よりポリグ ラフ上の覚醒の方が多い事例 (裖婦群 $: \mathrm{L} \cdot \mathrm{M} ・ \mathrm{~N}$ ) とであった，前者の場合の理由は，「はっきり と夢をみた」または「ぼんやりと体位変換した」 であり，いずれも起床時に睡眠の満足は得られ ていた.これは, 通常の睡眠時にも認められる ことである．解離が大きく，起床時に睡眠の満 足が得られない例は，遠藤により8)，神経質性 不眠者において報告されている，ポリグラフ上 では正常者と同じ睡眠経過を示すにも関わらず 主観的面でかなりのずれを生じ，入眠潜時の長 期化・睡眠時間の短縮化・睡眠深度の浅さとし て表し，自己に不利な体験として睡眠を評価す る, いわゆる主観的虚構性を指摘している. 
一方, 後者の場合は全例裖婦であり, 主観的 覚醒よりポリグラフ上の覚醒の方が多く. 覚醒 の評価は寛大であった。通常, 解離が大である ことは問題視されるが, 褯婦の場合は精神的な 面での異常性は認められなかった。

Rubin $^{9)}$ によると, 分娩後 $3 \sim 4$ 週間は, 工 ネルギーが充分でなく横になりたいと思っても， 母親としての“すべきこと”に振り回され，そ のらえ $3 \sim 4$ 時間毎に昼夜関係なく起きる新生 児の世話のために, 睡眠が中断され疲労感が犠 牲的感覚を生み出すが, その後は身体回復とと もに $6 \sim 8$ 時間前後の連続した眠りが得られエ ネルギーが回復してくると述べている. 褾婦群 の途中覚醒は裖婦自身の原因ではなく, 新生児 の世話や授乳のためという特定の理由によるこ

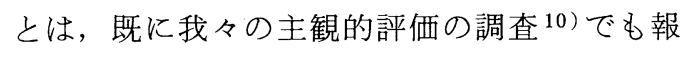
告した. Karacanら11)の研究においても, 産 裷期の覚醒では, 女性は睡眠が障害されたと考 えるよりむしろ，新生児の世話をする，受け入 れるといら母親なるものへの準備機能としてう けとる, 正常な身体的適応であると示唆してい た。

さらに本研究の結果でも, 途中覚醒の感情と して, 褛婦群ではほとんどが「しかたがない」 と考光, 覚醒の必然性を認識していた。産裖 7 週の経産婦の裖婦 (事例L)は, ポリグラフ所見 では頻回の覚醒であるが，主観的な睡眠深度の 変動はなく, 覚醒に対する身体的・心理的慣れ を示すものと思われる。

\section{3 ）睡眠の満足度}

睡眠全体に満足感を示さなかった事例のうち, 事例 $\mathrm{H}$ は妊娠中期で, ポリグラフ所見では全睡 眠経過時間のほ汴中央の時間帯に途中覚醒が認 められ，睡眠が二分されていた．裖婦群の事例 Mは，途中覚醒が多く認められた。しかしポリ グラフ所見において, 同様に途中覚醒が多く認 められる, 妊娠末期の事例 $J \cdot K$ や, 裖婦の事例 $\mathrm{L} \cdot \mathrm{N} \cdot \mathrm{O}$ は途中覚醒に対して否定的な感情もな く睡眠全体に満足感を示していた.この点にお いては, 先の我々の調査による, 妊娠 ・ 産裖期 による睡眠の満足感の差異, すなわち睡眠の満 足感は, 妊娠が進行するほど不良となり, 産裖 早期にはさらに不良となるといら結果と異なる
見解であった.

\section{2. 妊娠各期之産裖早期の睡眠推移}

睡眠パラメータによる非妊娠期から妊娠, 産 褯早期をでの睡眠の推移についてみると, 妊婦 群は非妊婦群に比べて睡眠率が低く, 覚醒時間 が多かった. 時期別には, 末期の方が初・中期 よりも睡眠率が低く, 産裖早期にはさらに低下 することがわかった. 覚醒回数の点においては 妊娠末期と産裖早期の間には差が認められなかっ たが，覚醒時間には差が認められた。これは， 途中覚醒の理由が異なっていたためと推察され る. 妊娠期には, おもに妊婦自身の身体的理由 で覚醒し, 産裖早期には新生児の世話のために 覚醒していた。

睡眠深度および睡眠周期の出現を見ると, 妊 娠が進行し末期になるほど，\%S4は少なくなり， 眠りが浅くなる傾向があった。しかし, 産裖早 期は末期に比べて\%S4増加の兆しがあった.

第 1 睡眠周期の時間帯は, 覚醒相から睡眠相 へ移る遷移帯として重要視する立場があり, 特 にS4 第 1 睡眠周期の長さとの間で正の相関 を認める報告がある12)。本研究においては, 妊娠週数と第 1 周期との間に有意な正の相関が 認められ，末期になる泀ど第 1 周期が長くなる 傾向があった. しかし妊婦の第 1 周期中の\%S4 は, 妊娠時期と負の相関が認められた. このこ とは, 妊娠末期といら生理学的条件が, 通常の 睡眠経過の進行を司る機序に, 何らかの影響を 及汭してると推察できる。宮下ら ${ }^{13)}$ も， REM 潜時は個人間変動(個人差)及び条件間変動(各 夜間変動)が大きい変数であることを報告して いる.

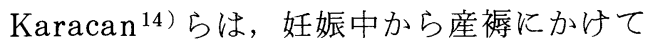
の終夜睡眠を調べた結果, 妊娠初期には, 眠気 が強く, 昼寝も多くなり, 睡眠時間が長いこと, 妊娠中期には通常の成人に近い眠りとなるが, 妊娠末期と分婏直後に抒いては覚醒時間が多く なり，とくに末期はS4とREMがより少なく， この傾向は産後 2 週目までに徐々に回復し増加 すると報告している. Petre-Quadens ${ }^{15)} ら も$ 同様の結果を報告している. この点においては, 本研究の結果も妊娠から産褛早期にかけてのSEI 
や\%4,\%REM の変化において, 同様の傾向で あった。

Karacan ${ }^{16)}$ は，妊娠末期に抑制されていたS4 が産裖期において，全睡眠時間が短いにもかか わらず，増加する点について，分婏時の身体的 エネルギーの消費がひとつの引き金になってい るのではないかと推察し，産䙏期においては， いかに短時間に効率よく眠っているかを指摘し ていた。

石束ら 17)は，月経周期にともなら主観的睡 眠の変化は 7 日の周期をもって示されると指摘 している。妊娠初期には，それまでの月経周期 に伴ら生理的な睡眠の変化に比べ，変化は大で

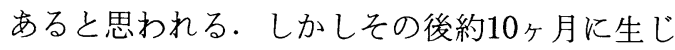
る睡眠の漸進的変化に適応し，産裖期の大きな 変化を迎える。その意味では，生理的な必然性 をもつ変化ではないだろらか。

\section{3. 看護への適用}

今後，妊娠中から産裖期にかけての睡眠の変 化について, 対象のパーソナリテイを考慮して 予期的に教育・指導することが重要であろら.

内分泌の変化にともなら女性の身体の調節機能 の巧みさを説明するとともに，生活上の睡眠の 工夫を指導の中に織り込むこと，家族に対して その変化への理解を教育し，心理的サポートを 促す必要性がある。 あた，眠りに関して悩みを もつ母親により多くの相談の機会を設けること も重要であろら.

\section{結論}

1. 妊婦および裤婦の終夜睡眠を事例別にみる 之, 主観的な睡眠深度経過図は前半単相性パター ンと前半多相性パターンとが認められた。前半 単相性パターンを示すものは，ポリグラフ所見 において通常成人の示す睡眠経過であった，前 半多相性パターンを示すものは，ポリグラフ所 見でmissed REM によるものと思われる第 1 周 期の延長が認められたもの，途中覚醒が頻回で 睡眠後半期にもS3, S4 が認められたものとが あった。

2. 主観的な途中覚醒の知覚は, ポリグラフ所
見と一致するものと, 解離するものとが認めら れた。解離を示すもののうち，裖婦においては 主観的な覚醒の知覚よりポリグラフ上の覚醒の ほらが多かった。

3. 睡眠パラメータから見ると, 妊婦群は非妊 婦群に比べて睡眠率が低いことから，覚醒時間 が多かった。時期別には，妊娠末期群のほうが 初期・中期群よりも睡眠率が低く，また末期に は眠りが浅くなっていた。産裖早期は，妊娠末 期よりさらに睡眠率が低くなっていたが，妊娠 末期に比べて\%S4は増加の傾向が認められた。

（本研究に際し統計検定についてのご助言をい ただきました統計数理研究所の高木廣文先生に 感謝いたします。本研究は昭和60年文部省科学 研究費No.60440099 (研究代表者近藤潤子) による研究の一部として行われたものである. 本研究の一部は, 第 8 回ならびに第 9 回日本看 護科学学会学術集会において，第14回日本睡眠 学会学術集会において発表したものである.)

\section{引用文献}

1) 堀内成子, 他：妊娠期における睡眠の主観的 評価に関する研究, 日本助産学会誌, 2(1),42$53,1988$.

2 ）堀内成子, 他：産裖早期における睡眠の主観 的評価; 妊娠期からの変化の追跡, 聖路加看 護大学紀要, $16,49-59,1990$.

3 ) Karacan, I., Williams, R.L. et al.: Some Implications of the Sleep Patterns of Pregnancy for Postpartum Emotional Disturbances, British Journal of Psychiatry, 115, 929-935, 1969.

4 ) Petre-Quadens, O., De Barsy, A.M. et. al. : Sleep in Pregnancy, Evidence of Foetal Sleep Characteristics, J. Neurol. Sci. , 4. , 600-605, 1967.

5 ) Rechtschaffen. A., Kales.A. 編, 清野茂訳 : 睡眠脳波アトラス，医歯訳出版，1971。

6 ）小林敏孝, 他：睡眠の単位構造としてのSleep Cycle とその出現過程, 脳波と筋電図, 11(3), 165-175, 1983.

7 ) Borbely, A.A.: A Two Process Model of Sleep 
Regulation, Human Neurobiol. , 1, 195-204, 1982 .

8 ) 遠藤四郎 : 神経質性不眠の精神生理学的研究, 精神神経雑誌, 64, 673-707, 1962.

9 ) Rubin, R.: Maternal Identity and the Maternal Experience, Springer Publishing Co. , 86-99, 1984.

10）前掲著 2

11）前掲著 3

12）前掲著 6

13）宮下彰夫，他：健常者の睡眠にみる睡眠変数
の変動性, 臨床精神医学, 16(7),949-954, 1987. 14）前掲著 3

15）前掲著 4

16) Karacan, I., Heine, W., Agnew, H.W. , Williams, R.L., Webb, W.b., and Ross, J.J. : Characteristics of Sleep Patterns during Late Pregnancy and the Postpartum Periods. Amer. J. Obstet. Gyn., 101, 579-586, 1968.

17）石束嘉和, 他：月経周期に伴ら自覚的睡眠感 の変動についての研究, 山梨医大誌, 4(3), 141-148, 1989. 